\author{
PETR DOBROVOLNÝ, RUDOLF BRÁZDIL, OLDŘICH KOTYZA, \\ HUBERT VALÁŠEK
}

\title{
EXTREME SUMMER AND WINTER TEMPERATURES IN THE CZECH LANDS AFTER A.D. 1500 AND THEIR CENTRAL EUROPEAN CONTEXT
}

\begin{abstract}
DOBROVOLNÝ, P., BRÁZDIL, R., KOTYZA, O., VALÁŠEK, H. (2010): Extreme summer and winter temperatures in the Czech Lands after A.D. 1500 and their Central European context. Geografie, 115, No. 3, pp. 266-283. - Extremely cold/mild winters (DJF) and extremely cold/warm summers (JJA) in the Czech Lands were derived from series of temperature indices based on documentary evidence (1500-1854) and from series of air temperatures measured at the Prague-Klementinum station (1771-2007) over the past 500 years. Altogether 24 cold winters, 23 mild winters, 18 cold summers and 21 warm summers emerged. Czech extremes were compared with the Central European temperature series and series of documentary-based temperature indices for the Low Countries, Germany and Switzerland. Analysis of composite sea level pressure fields confirms advection of cold air from the north-west (extremely cold summers) or from the east (extremely cold winters). Mild winters are related to warm airflow from the west or south-west and extremely warm summers to the influence of high pressure related to the Azores High. Spatial correlations of extremes for winters proved better than for summers. We demonstrate that documentary evidence explains temperature variability for winter better than it does for the other seasons.

KEY WORDS: documentary evidence - extremely cold/mild winters - extremely cold/warm summers - Central European temperature series - Czech Lands - Central Europe - past 500 years.

This paper was prepared with financial support from Czech Science Foundation project No. P209/10/0309 Effect of historical climatic and hydrometeorological extremes on slope and fluvial processes in the Western Beskydy Mts. and their forefield.
\end{abstract}

\section{Introduction}

According to the fourth IPCC report (Solomon et al. 2007) "confidence has increased that some extremes will become more frequent, more widespread and/ or more intense during the 21st century". The anticipated higher frequency of extremes, such as heat waves and droughts, is related to recent global warming (Karl, Easterling 1999; Hegerl et al. 2006). A better insight into the frequency and intensity of such events requires a long and homogeneous meteorological series. Systematic temperature measurements started at several places in Central Europe during the 18th century (Camuffo, Jones 2002; Jones, Briffa 2006). Such long instrumental series have been used to analyze temperature fluctuations and extremes over the period, during which the role of the anthropogenic factor has become progressively more apparent (Solomon et al. 2007). However, direct meteorological measurements are not available for the previous centuries, when temperature variability was driven by only natural forcings. 
Temperature variability in the pre-instrumental period may be described in terms of observations of natural proxies (Bradley 1999; Jones et al. 2009). On the other hand, useful information for temperature reconstructions in Central Europe may be found in man-made archives. This comprises various types of direct or indirect information about the weather and climate that have been included in documentary sources such as annals, chronicles, "books of memory" and diaries, visual daily weather observations, correspondence, financial records, newspapers etc. (for more details see e.g. Brázdil et al. 2005, 2010; Pfister et al. 2008; Brázdil, Dobrovolný 2010). Unsurprisingly, much of the documentary evidence often concentrates on extremes (Pfister 1992). Written historical reports usually provide detailed descriptions of a range of weather extremes and climate anomalies that attracted attention forcefully, particularly when compared with "normal" weather. These features, together with a precise temporal resolution, sometimes even to a sub-daily scale, are the prerequisite of documentary evidence for the study of weather extremes and climate anomalies.

Although documentary sources in Central Europe become abundant largely after the 16th century (Pfister et al. 1999), valuable sources have also been found for the later Medieval period, for instance in Germany (Glaser 2008), Switzerland (Pfister 1992), the Low Countries (Shabalova, van Engelen 2003) and the Czech Lands (Brázdil, Kotyza 1995, 2000). The qualitative and descriptive character of much of the documentary data does not prevent its use for quantitative temperature reconstructions after A.D. 1500 (Luterbacher et al. 2004, 2007; Xoplaki et al. 2005; Dobrovolný et al. 2009, 2010; Brázdil et al. 2010) or for the whole millennium (Glaser, Riemann 2009). Documentary evidence has also been used recently to study circulation dynamics for Europe over the past 500 years (Luterbacher et al. 2010), and the results of documentary-based temperature reconstructions have been compared to global circulation model millennium runs (Zorita et al. 2010). Temperature extremes reconstructed from tree-ring maximum late-wood density and from documentary evidence have been compared for Central Europe over the last 500 years by Battipaglia et al. (2010).

This contribution centres upon on investigation of extremely cold/mild winters and cold/warm summers in the Czech Lands over the past 500 years. Extreme seasons were derived from systematic instrumental measurements and from documentary evidence. The data sources are described in the second section. In section three we explain the basic methods used for characterization of extreme seasons. In section four we categorise extreme seasons found in the Czech Lands. Section five discusses these extreme seasons in the Central European context and summarizes the potential of documentary evidence for the study of temperature extremes. The last section includes some concluding remarks.

\section{Data}

The longest series of air temperature measurements in the Czech Republic come from Prague Klementinum (a former Jesuit college). Systematic measurements started on 1 January 1775 , but some previous observations have en- 
abled extension of monthly means back to 1771 (Hlaváč 1966). Thermometers were located in the courtyard of the college. Their position changed several times, as indeed did the shape of the court in the course of various reconstructions (for details, see Brázdil, Budíková 1999). The Prague measurements have been influenced by the urban heat island and its intensification. During the 20th century, the effect of heat island caused a statistically significant rise in winter temperatures at a rate of $0.06{ }^{\circ} \mathrm{C}$ per decade; the corresponding value for summer temperatures, $0.01^{\circ} \mathrm{C}$ per decade, is insignificant (Brázdil, Budíková 1999). The Prague series was tested for relative homogeneity in comparison with ten Central European homogeneous series in the HISTALP database (Auer et al. 2007) and then homogenized (Dobrovolný et al. 2010). Reference temperature series were also corrected for insufficient radiation protection for the early thermometers (Böhm et al. 2010). Winter and summer mean temperature deviations (reference period 1961-1990) for Prague-Klementinum since 1771 were used for further analysis of extremely cold/warm seasons.

Extreme seasons in the pre-instrumental period were derived from Czech documentary evidence, also partly used for quantitative temperature reconstructions (Dobrovolný et al. 2009, 2010). Critically evaluated and interpreted documentary data were first transformed to monthly temperature indices on a seven-degree scale in which an index value of -3 means extremely cold, -2 very cold, -1 cold, 0 normal, +1 warm, +2 very warm, +3 extremely warm patterns. Seasonal indices are constructed as a sum of corresponding monthly values and can vary in the range -9 to +9 (for more details see e.g. Brázdil et al. 2005). Czech temperature indices were derived for the period 1500-1854. However, relevant information for some months or seasons was missing. Thus for the whole period in question (355 years) 318 (90\%) DJF and 254 (72\%) JJA seasons were indexed. Extremely cold/warm seasons derived from Czech indices were compared with temperature indices from Germany and Switzerland as well as with reconstructed Central European temperature series. Central European temperature series was derived from German, Swiss and Czech indices for the period 1500-1759 and from 11 Central European instrumental series for the period 1760-2007. An important feature of the Central European temperature series with respect to extremes is the fact that the variability of reconstructed winter and summer temperatures does not decrease as one moves backwards in time (Dobrovolný et al. 2010).

\section{Methods of analysis}

The possibilities for definition of extremes from seasonal temperatures (measured or derived from proxy data) are limited. Classical extreme value analysis uses two basic approaches for extracting extreme data. The block maxima method finds maximum (or minimum) value in intervals of equal length (Katz et al. 2004). An alternative is to define an overall threshold and to consider all peaks over this threshold in a corresponding time interval (von Storch, Zwiers 1999). The character of the data used in this study places "peak over threshold" method before that of "block maxima". A threshold value is frequently determined as a certain multiple of standard deviation (von Storch, Zwiers 1999). However, where distribution is skewed or when data distribu- 

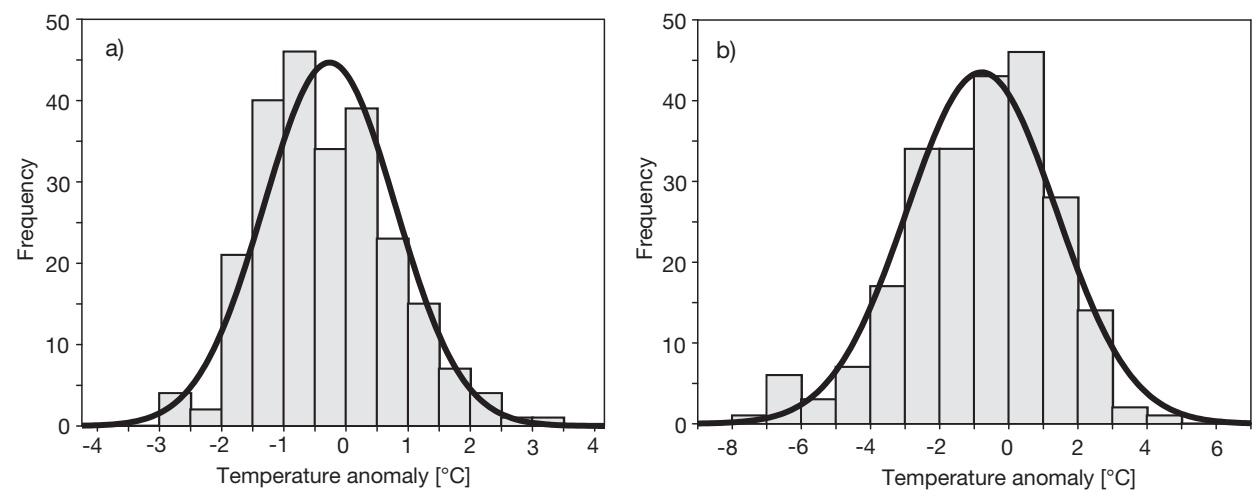

Fig. 1 - Histograms of mean winter (a) and summer (b) temperature anomalies from PragueKlementinum in the period 1771-2007, fitted with the normal distribution. Reference period 1961-1990.

tion deviates significantly from normal, the number of extremes on each tail of the distribution will be different. In such cases percentiles may be used for delimitation of extremes. Figure 1 shows histograms of winter and summer Prague-Klementinum mean temperatures fitted with normal distribution. From Figure 1 and the basic statistics in Table 1, it follows that winter temperatures are negatively skewed while summer temperatures are skewed positively. Significant differences from the normal distribution in each histogram were demonstrated by Shapiro-Wilks test at a significance level of 0.05 .

As the Czech index series show the same features as instrumental ones (Table 1), the 5th and the 95th percentiles were used as thresholds to define extremely cold/mild winters and extremely cold/warm summers in both documentary and instrumental data. These percentiles give a reasonable number of cases for subsequent comparison. Because the distribution of index series is derived from discrete values that suppress data variability, different thresholds (e.g. the 10th and the 90th percentiles, not shown) define a much higher number of cases in comparison with measured temperatures. The strip charts in Figure 2 present selected extreme seasons in both data types with respect to distribution in all seasons. All winter seasons in the present article are determined by the year of January (e.g. the 1540 winter is that of $1539 / 1540$ ).

Tab. 1 - Basic statistics of Czech temperature indices (1500-1854) and Prague-Klementinum measured temperatures (1771-2007) for winter and summer seasons (temperatures expressed as anomalies from the 1961-1990 reference period); $n$ - number of values, P05 (P95) - 5th (95th) percentile, sd - standard deviation, skew - skewness. Mean, min, max, $P 05, P 95$ and $s d$ are expressed in ${ }^{\circ} \mathrm{C}$ for winter and summer temperatures.

\begin{tabular}{|lcccccccr|}
\hline Series & $\mathrm{n}$ & mean & $\min$ & $\max$ & P05 & P95 & sd & skew \\
\hline DJF index & 318 & -1.0 & -9 & 7 & -6 & 4 & 3.1 & 0.0 \\
DJF temperature & 236 & -0.8 & -7.1 & 4.9 & -4.8 & 2.5 & 2.2 & -0.5 \\
JJA index & 254 & 0.4 & -6 & 8 & -4 & 5 & 3.0 & 0.2 \\
JJA temperature & 237 & 0.3 & -2.9 & 3.4 & -1.7 & 1.6 & 1.1 & 0.4 \\
\hline
\end{tabular}



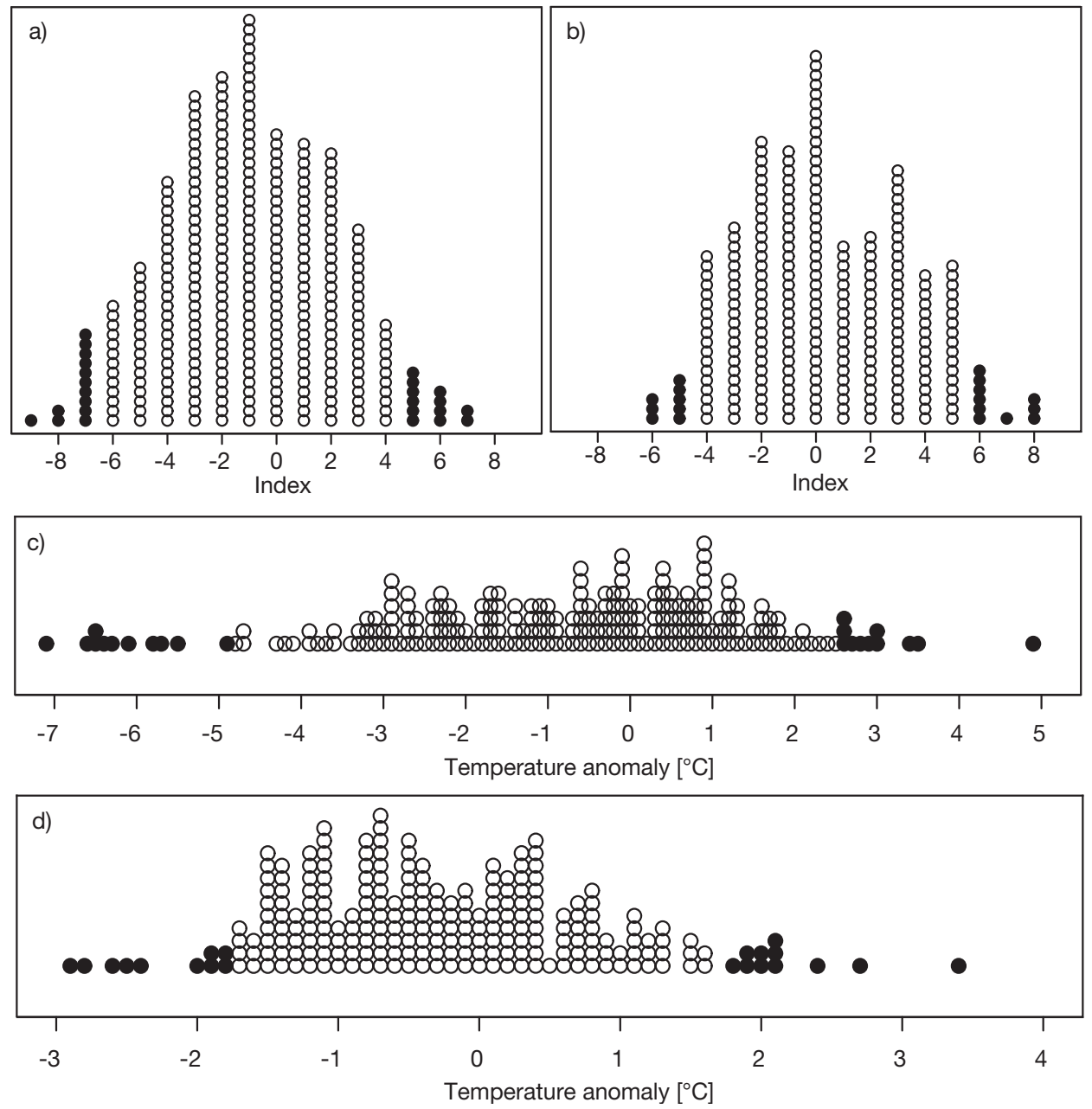

Fig. 2 - Distribution of winter (a) and summer (b) Czech temperature indices (1500-1854) and winter (c) and summer (d) Prague-Klementinum temperature anomalies (1771-2007). Reference period 1961-1990. Black circles highlight extreme seasons delimited at the 5th and the 95 th percentiles.

\section{Extreme winters and summers in the Czech Lands after A.D. 1500}

The first report from the Czech Lands of a long and severe winter was that of A.D. 974/975, mentioned by the "Monk of Sázava" in his additions to the Kosmas Chronicle, which is accepted as the first historically credible source. Further reports come from the 1120s (cold winters 1122, 1123, mild winters 1124,1126 , warm summers 1122,1123 ) with an increasing number of extreme seasons in the following centuries (Brázdil, Kotyza 1995). Such information is closely dependent on the sources available and is erratic, usually covering 
certain particular time intervals. Better data coverage on extreme seasons for the Czech Lands can be obtained only from the 16th century onwards.

Extremely cold/mild winters and extremely cold/warm summers in the Czech Lands after A.D. 1500 are presented in Figure 3. All these extremes are projected onto the Central European temperature reconstruction (Dobrovolný et al. 2010), for several reasons. Firstly, annually resolved temperature reconstructions for the Czech Lands exist only from 1718 (Dobrovolný et al. 2009). Secondly, combination of the "national" index series at regional level is one method of overcoming the spatial and temporal heterogeneity and incompleteness of documentary data. Finally, the Central European temperature reconstruction was compiled from German, Swiss and Czech index series that significantly correlate between one another. This holds especially true for winter and, with the exception of the period around the $1750 \mathrm{~s}$, for summer as well (see Figure 6 in Dobrovolný et al. 2010).

Smoothed winter temperatures in Central Europe were lower compared to the mean of the 1961-1990 reference period for almost the whole period from A.D. 1500. This finding highlights the exceptionality of high winter temperatures in recent decades. Overall long-term winter temperature amplitude may be expressed as the difference between the warmest and the coldest temperatures found in series smoothed with 30-year running averages. The warmest 30-year winter period, 1973-2002, was $0.7{ }^{\circ} \mathrm{C}$ above the reference period. The coldest 30-year period occurred in the last third of the 16th century (1572-1601) with a mean temperature $1.8{ }^{\circ} \mathrm{C}$ below the reference period. Taking these 30-year means as a long-term average ("climatology"), the difference of $2.5^{\circ} \mathrm{C}$ between them may be considered as a rough estimate of longterm temperature range from Little Ice Age climate to present global warming derived from documentary evidence.

According to the 5th and the 95th percentiles, 13 winters in the Czech temperature indices over the 1500-1854 period were classified as extremely cold and 12 winters as extremely mild. The number of negative and positive extremes over the instrumental period (1772-2007) is the same (11 seasons). Cold winters at the end of the 16th century occurred after a relatively long period of decreasing temperatures starting around the 1540s (Figure 3a). Decreasing winter temperatures are also typical for the end of the 17th century while an opposite positive trend occurred at the beginning of the 18th century. The cold spell around the end of the 17th century may be related to the late Maunder Minimum of solar activity (Eddy 1976). The same patterns occurred in the European temperature reconstruction (Luterbacher et al. 2004). However, neither in Central European temperature reconstruction nor in Czech extreme winters clear evidence can be found for the unusually warm 1730s and the extremely cold winter of 1740 documented in some series in north-western Europe (Jones, Briffa 2006). The only extremely mild winter in this period detected in Czech documentary data occurred in 1724. A cluster of both positive and negative extremes around the 1800s is - despite below-normal winter temperatures - rather related to a higher inter-annual variability.

Some features valid for winter temperatures can also be found for summer temperatures (Fig. 3b). Almost identical are the occurrences of the coldest (1569-1598) and the warmest (1978-2007) 30-year periods. However, as the variability of summer temperatures is generally lower, the difference between 
a)

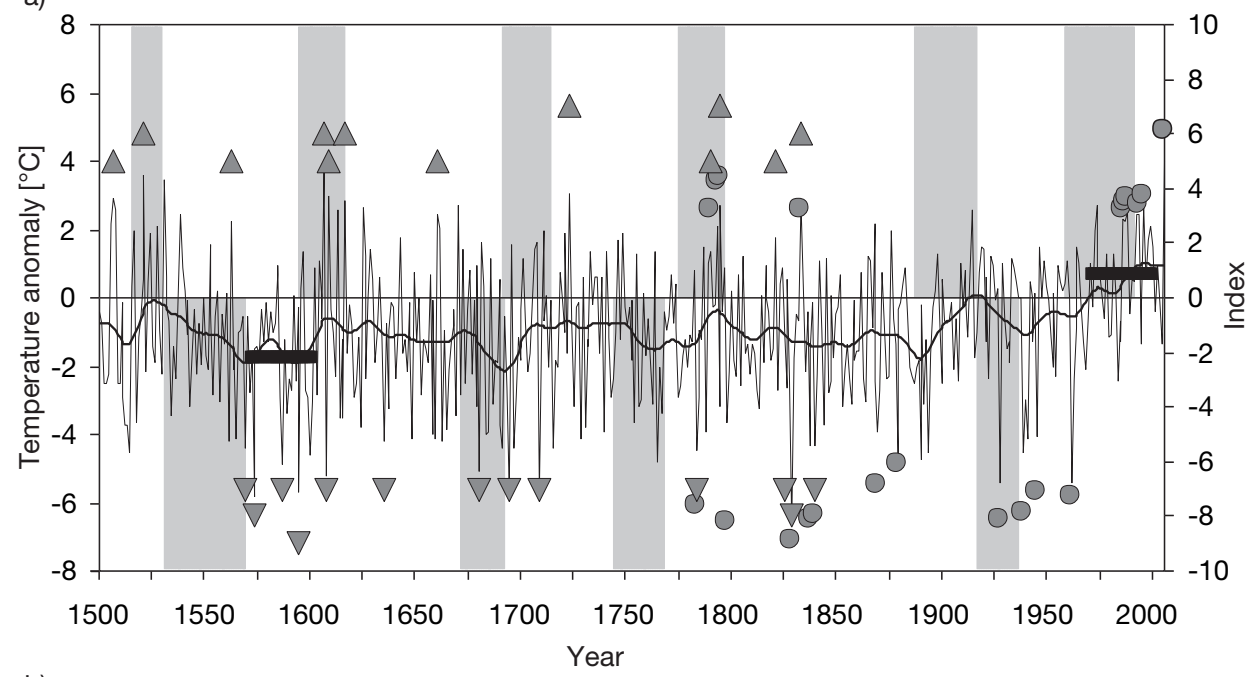

b)

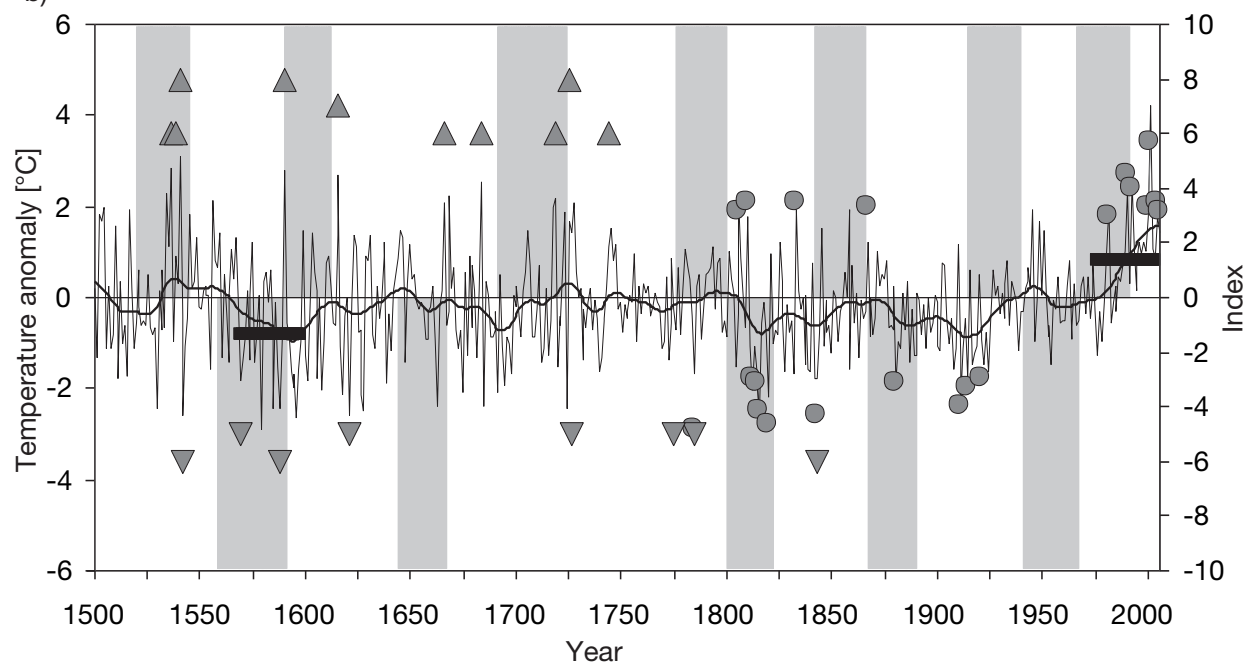

Fig. 3 - Winter (a) and summer (b) Central European temperature anomalies (reference period 1961-1990) smoothed with a 30-year Gaussian low-pass filter in the period AD 1500-2007. Horizontal bars indicate coldest/warmest 30-year non-overlapping periods. Vertical bars indicate periods of continuously decreasing/increasing running linear trends over the 30-year period. Triangles indicate extremely cold/warm seasons in the Czech documentary-based index series (1500-1854), circles in the Prague-Klementinum temperature series (1771-2007).

them is only $1.6^{\circ} \mathrm{C}$. On the decadal scale, the most pronounced period of decreasing summer temperatures started at the 1540s and also covered the second half of the 16th century. A rising temperature trend from the cold 1690s to the $1720 \mathrm{~s}$ is well expressed. The same is also true of recent warming in the last decades of the 20th and the beginning of the 21st centuries. Extremely warm summers detected in the last three decades of the Prague-Klementinum 
series form the most distinct period of their higher occurrence. There are no negative summer extremes in the second half of the 20th century. Extremely cold summers in the instrumental period occurred in the 1800s-1820s (1809, $1813,1816,1821)$ and in the 1910s-1920s $(1913,1916,1923)$. Altogether eight negative and ten positive summer extremes emerged from Czech documentary-based indices (1500-1854). The corresponding number of summer extremes defined in Prague-Klementinum series is 10 and 11 respectively (1771-2007).

The consistency of extreme seasons found in Czech documentary and instrumental data may be demonstrated for the overlapping period of 1771-1854. Altogether four extremely cold winters were defined in both sources (1784, 1799 , 1830, 1841). Only winter 1838, indicated by measured temperatures, was not detected in Czech index series. However, the index -6 for this winter is only the threshold value and indicates a "very cold" character for this season. Slightly less agreement emerges in extremely mild winters, with three identical extremes in both data sets (1791, 1796, 1834). Winter 1794, defined as extremely mild in Prague measurements (deviation $+3.4^{\circ} \mathrm{C}$ ), is partly underestimated in the index series (index 4). On the other hand, the extremity of the 1822 winter comes from documentary sources (index 5) while according to Prague temperatures it was not so mild (deviation $+2.0^{\circ} \mathrm{C}$ ).

Compared to winter results, extreme summers detected in the two data sets give less agreement (Fig. 3b). There may be different reasons for this. One may be related to data quality. There are far more missing values in the summer index series compared with winter (see section 2). Further, different series of winter indices correlate better compared with summer index series. Finally, as discussed in section 5, winter temperature extremes in Central Europe usually impact upon larger areas than do summer temperature extremes. More summer extremes are to be found in the measured series. In terms of the documentary-based indices, there were no extremely warm summers and only two extremely cold summers $(1785,1844)$ in the overlapping period 1771-1854. The extremely cold summer of 1844 was also delimited in measured temperatures.

\section{Discussion}

5.1. Validation of Czech temperature extremes in the Central European context

The Czech extremes detected for the pre-instrumental period through documentary proxies may be validated against documentary-based indices from Switzerland (Pfister 1999) and Germany (Glaser 2008) and also partly against temperature indices from the Low Countries (Shabalova, van Engelen 2003). Whereas German and Swiss indices were derived using the same methodology as Czech indices, indices for the Low Countries used a similar 9-degree scale at seasonal level, but they were derived for different seasons: November-March for "winter" and May-September for "summer".

Temperature indices for extreme winters and summers detected from Czech documentary data are summarized in Figure 4. Generally, there is a better agreement for negative winter extremes (Fig. 4b) compared to positive winter 
anomalies in Central European documentary sources (Fig. 4a). All Czech extremely cold winters show negative temperature deviations in neighbouring countries and they range from -2 to -9 on a common scale. Extremity of mild winters is less expressed in documentary indices; it mostly reaches index value 7 on the 9-degree scale, with the warm winter 1607 in Switzerland (index 8) as the only exception. All selected mild winter seasons in Central European countries show positive anomalies. Less agreement follows from comparison of Central European index series with Low Countries data. However, most of the extremely mild winters in Czech Lands had a positive temperature anomaly in Low Countries. The most obvious difference in the evaluation of extremely mild winters concerns the 1506 winter, evaluated through Low Countries sources as rather cold.

Evaluation of Central European extremely warm (Fig. 4c) and extremely cold (Fig. 4d) summers gives very similar results and shows to some extent an "inverse" pattern in comparison with winters. Extremity is better expressed for warm summers than for cold ones. This is especially evident for Czech and German indices. The far larger number of differences in the evaluation of extreme summers in comparison with winters is related to the various factors responsible for their occurrence in Central Europe. While extremely cold/mild winters are more related to large-scale circulation patterns, summer extremes are to a greater extent conditioned by other effects as well, such as radiation. This is also related to the fact that summer temperature correlations between different places fall away with increasing separation distance much more quickly than do winter temperatures (see e.g. Fig. 5 in Dobrovolný et al. 2010).

Typical large-scale circulation patterns in the extreme winters and summers defined from Prague-Klementinum temperature series may be characterized with seasonal sea level pressure fields. Pressure fields were reconstructed as a $5 \times 5^{\circ}$ grid with a seasonal resolution by Küttel et al. (2009) for the period 1750-1849 and supplemented from the HadSLP2r database (Allan, Ansell 2006) for the remaining period (1850-2007). For each type of extreme (extremely cold/mild winter and extremely cold/warm summer), corresponding seasons were averaged and expressed as anomalies with respect to a 1961-1990 reference period. The significance of these anomalies was assessed by t-test, and regions of significant differences are marked with black dots in Figure 5.

Mean winter and summer sea level pressure (SLP) fields in Central Europe are characterized by relatively lower air pressure between the Azores High and the Asian High. The former high is more important in summer (Fig. 5d), the latter in winter (Fig. 5a). Pressure to the south and north of this belt decreases. During extremely cold winters (Fig. 5b) in the Czech Lands the position and intensity of the Icelandic Low correspond to its normal situation. Higher SLP values in north-eastern Europe, along with a decrease of pressure in Mediterranean, favour intensification of cold eastern airflow. For extremely mild winters (Fig. 5c), a decrease of pressure south-west of Europe is related to a weakening of Azores High and an increase of air pressure in northern Europe that favours a warm airflow. Moreover, we found that both the SLP decrease in the Mediterranean (cold winters, Fig. 5b) and the SLP decrease over the Atlantic (warm winters, Fig. 5c) are statistically significant. 

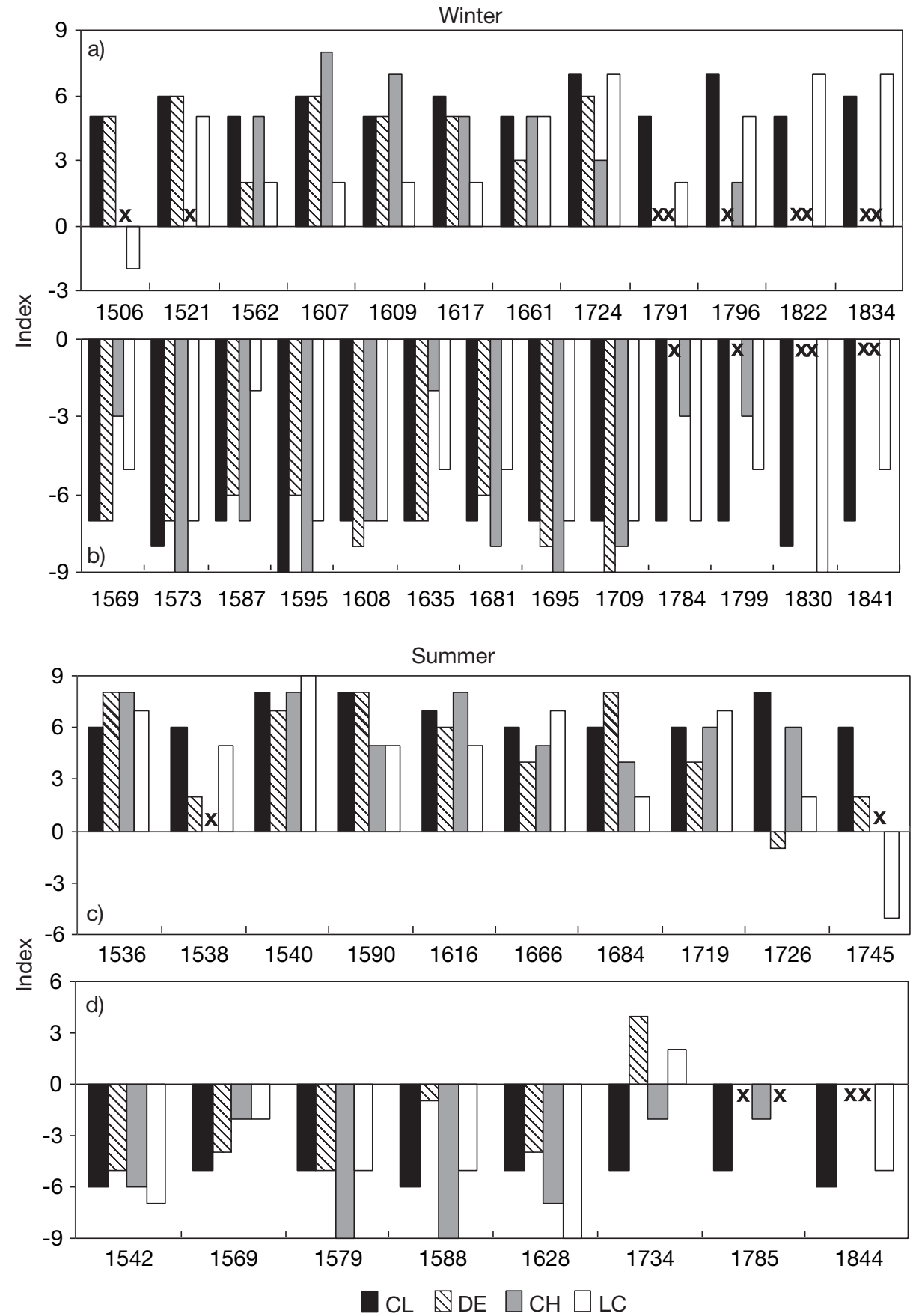

Fig. 4 - Documentary-based temperature indices for extremely mild (a) and extremely cold (b) winters and extremely warm (c) and extremely cold (d) summers for the Czech Lands (CL), Germany (DE), Switzerland (CH) and the Low Countries (LC) in the period 1500-1854, $\mathrm{x}-$ missing index. 
a)

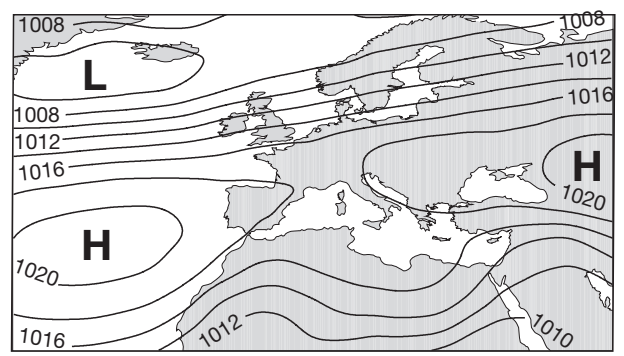

b)

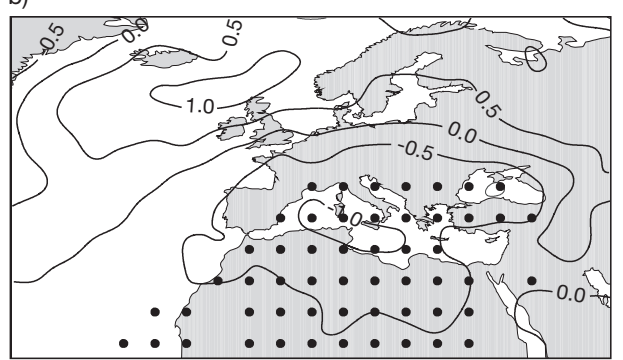

c)

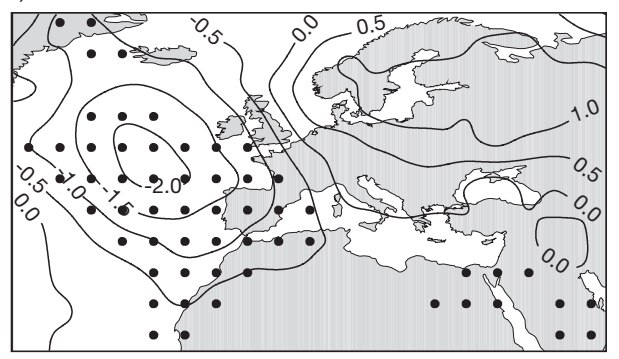

d)

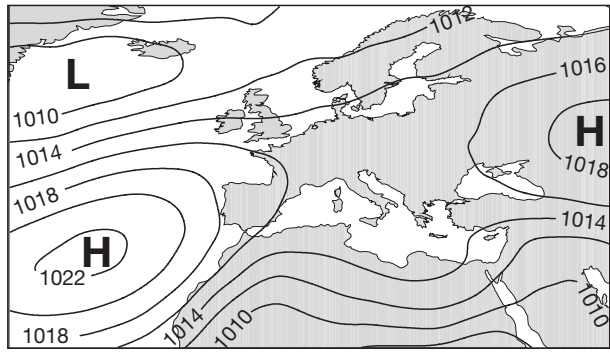

e)

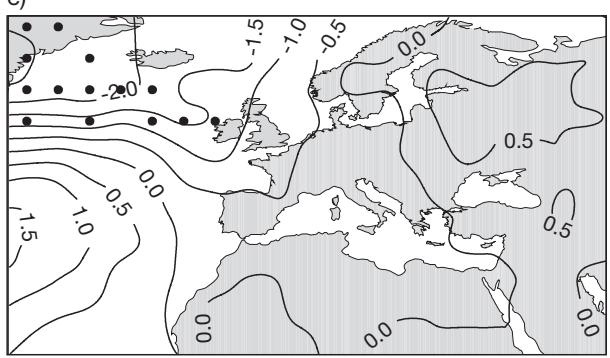

f)

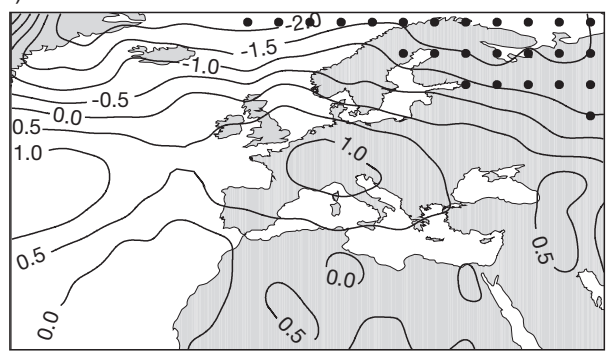

Fig. 5 - Sea level pressure fields derived from Küttel et al. (2009) for the period 1750-1849 and from HadSLP2r (1850-2007): (a) winter (DJF) mean 1961-1990, (b) mean SLP anomalies for extremely cold Prague winters, (c) mean SLP anomalies for extremely mild Prague winters, (d) summer (JJA) mean 1961-1990, (e) mean SLP anomalies for extremely cold Prague summers, (f) mean SLP anomalies for extremely warm Prague summers. Reference period 1961-1990, units hPa. Black dots delimit areas where SLP anomalies are statistically significant at $95 \%$ significance level according to t-test.

In extremely cold summers (Fig. 5e) there is an intensification of dipole pattern with above-normal sea level pressure values in the Azores area and a negative anomaly over Iceland. Such a pressure distribution means a positive phase of the North Atlantic Oscillation and an intensification of cold northwest airflow from the Atlantic Ocean to Central Europe. A clearly expressed positive SLP anomaly in Central Europe intensifying the influence of the Azores High is related to extremely warm summers (Fig. 5f). However, the SLP anomalies revealed in extreme summer seasons in Central Europe are not statistically significant (Fig. 5e, f).

In addition to typical sea level pressure patterns in extreme seasons, variability was also studied using maps of SLP standard deviations (not shown 
here). Both cold and warm seasons are typified by higher variability over the Atlantic and suppressed variability in the region of Central Europe. This indicates that sea level pressure distribution within extremely cold/warm winter and summer seasons is very consistent in Central Europe.

Several extreme seasons detected in Czech index series and confirmed on the Central European scale may be related to volcanic forcing. For example, the extremely cold summer of 1816 , often reported as "the year without a summer", followed the 1815 Tambora eruption (Písek, Brázdil 2006; Fischer et al. 2007; Trigo et al. 2009). The extremely cold winter of 1784 , after the Laki eruption, was also exceptional for the extraordinary floods that occurred all over Europe (Brázdil et al. 2010).

\subsection{Specific features of temperature extremes derived from documentary data}

Documentary evidence as a source of information on weather extremes and climate anomalies has its strengths and drawbacks. The high proportion of written reports related to extreme events has already been mentioned elsewhere (e.g. Pfister 1992; Brázdil et al. 2005; Jones et al. 2009). To some extent there is a trade-off between number of reports and percentage of extremes occurring in available sources; this is typical especially of the mediaeval period with its lower data density (Brázdil, Kotyza 1995). This may lead to a problem for climate reconstruction in that, by their very definition, extremes represent only the tails of the distribution of the proxy used and such incomplete information is insufficient for reconstruction. However, as presented by Rodrigo (2008), even the frequency of positive and negative extremes in index series may be used with success for rainfall reconstruction.

Documentary sources are the only evidence directly related to the socioeconomic impacts and detailed description of individual events, and very often permit a precise picture of intensity, spatial extent and duration to be drawn up. On the other hand, temperature extremes are mostly referred to in subjective terms (e.g. when an author compares a current extreme with others that he has experienced) or indirectly (when the intensity of an extreme is inferred from its impacts). Both cases may be successfully managed as part of the process of data interpretation and indexing. However, the selection of any ordinal scale involves suppression of the variability of the target variable and does not allow a precise quantitative reconstruction, mainly of the most outstanding values. This feature of index series is also apparent in this study. The three most negative $(1542,1588,1844)$ and the three most positive $(1540$, $1590,1726)$ summer Czech indices have the same index value ( -6 and +8 respectively), but their further ranking can be done only with the help of additional information (e.g. from neighbouring countries). The above-mentioned problems of lower variability are not crucial to what have become known as the (bio)physically-based proxies, which are related to such processes as the freezing of water or the melting of ice (Leijonhufvud et al. 2008, 2010) and/or the occurrence of certain phenophases (Chuine et al. 2004; Meier et al. 2007; Brázdil et al. 2008). Moreover, it is usually no problem to define a set of extreme seasons from index series that are spatially coherent and reflected in 
other proxies, such as tree-rings (see e.g. Battipaglia et al. 2010). However, it may prove less easy to range such extremes quantitatively.

Reconstructed temperatures can be dependent on the method used for reconstruction. For example, linear regression methods generally suppress the variability and the final value is more reduced the more the real value deviates from the "normal". This can be partly overcome by "composite plus scaling" methods that adjust variance of reconstructed temperatures to be identical to the variance of target temperatures in the overlapping period (Esper et al. 2005). Such scaling changes the variability of reconstructed series and has an effect on their amplitude. Underestimation of the amplitude is a common problem of all proxy-based reconstructions (Bürger 2007) and careful study of the variability of proxy-based reconstructions is required.

Documentary evidence is usually abundant for a number of centuries past, but with the steady spread of instrumental measurements some typical sources of descriptive documentary evidence disappear or historical climatologists stop collecting such data. This sometimes hampers the acquisition of a sufficiently long overlapping period between documentary data and target temperatures. Moreover, extremes might not be expressed at all in short calibration/verification periods.

\section{Conclusions}

This study demonstrates that both documentary and instrumental data can be successfully used for the detection of extremely cold/mild winters and extremely cool/warm summers in the Czech Lands over the past 500 years. As mentioned by Jones et al. (2009), important climatic features such as regionally very mild or cold winters and/or very warm or cool summers can be masked in global or hemispheric reconstructions that emphasize the importance of regional climate reconstructions and study of weather extremes and climate anomalies on a local and regional scale.

As follows from this paper, documentary data are especially valuable for detection of winter extremes, with better agreement with those derived from documentary and instrumental data. Less agreement for summers may be related to a lower documentary data density as well as weakly-pronounced large-scale circulation patterns and a more important role being played by meso-scale processes.

The most distinct cluster of extremely mild winters and warm summers in the last two decades can be considered as a piece of evidence of recent global warming on a regional scale. Analysis of sea-level pressure anomalies for the extreme seasons detected shows that most of seasonal extremes are related to large-scale circulation patterns over Europe. Because documentary data can be interpreted at monthly resolution in Central Europe for the last 500 years, there is a huge potential for using them further for verification of climate anomalies detected through natural proxies (e.g. Battipaglia et al. 2010).

Acknowledgements: We would like to thank Tony Long (Svinošice) for English style corrections. The anonymous reviewer is acknowledged for useful and constructive criticism of the manuscript. 


\section{References:}

ALLAN, R., ANSELL, T. (2006): A new globally complete monthly historical gridded mean sea level pressure dataset (HadSLP2): 1850-2004. Journal of Climate, 19, No. 22, pp. 5816-5842.

AUER, I., BÖHM, R., JURKOVIC, A., LIPA, W., ORLIK, A., POTZMANN, R., SCHÖNER, W., UNGERSBÖCK, M., MATULLA, C., BRIFFA, K., JONES, P., EFTHYMIADIS, D., BRUNETTI, M., NANNI, T., MAUGERI, M., MERCALLI, L., MESTRE, O., MOISSELIN, J. M., BEGERT, M., MÜLLER-WESTERMEIER, G., KVETON, V., BOCHNICEK, O., STASTNY, P., LAPIN, M., SZALAI, S., SZENTIMREY, T., CEGNAR, T., DOLINAR, M., GAJIC-CAPKA, M., ZANINOVIC, K., MAJSTOROVIC, Z., NIEPLOVA, E. (2007): HISTALP - historical instrumental climatological surface time series of the Greater Alpine Region. International Journal of Climatology, 27, No. 1, pp. 17-46.

BATTIPAGLIA, G., FRANK, D., BÜNTGEN, U., DOBROVOLNÝ, P., BRÁZDIL, R., PFISTER, C., ESPER, J. (2010): Five centuries of Central European temperature extremes reconstructed from tree-ring density and documentary evidence. Global and Planetary Change. Doi:10.1016/j.gloplacha.2010.02.004.

BÖHM, R., JONES, P. D., HIEBL, J., BRUNETTI, M., FRANK, D., MAUGERI, M. (2010): The early instrumental warm-bias: a solution for long central European temperature series 1760-2007. Climatic Change, 101, No. 1-2, pp. 41-67.

BRADLEY, R. S. (1999): Paleoclimatology. Reconstructing climates of the quaternary. Academic Press, San Diego, London, Boston, MA, New York, Sydney, Tokyo, Toronto, $610 \mathrm{pp}$.

BRÁZDIL, R., BUDÍKOVÁ, M. (1999): An urban bias in air temperature fluctuations at the Klementinum, Prague, the Czech Republic. Atmospheric Environment, 33, No. 24-25, pp. 4211-4217.

BRAZZDIL, R., DEMARÉE, G., DEUTSCH, M., GARNIER, E., KISS, A., LUTERBACHER, J., MACDONALD, N., ROHR, C., DOBROVOLNÝ, P., KOLÁŘ, P., CHROMÁ, K. (2010): European floods during the winter 1783/1784: scenarios of an extreme event during the 'Little Ice Age'. Theoretical and Applied Climatology, 100, No. 1-2, pp. 163-189.

BRÁZDIL, R., DOBROVOLNÝ, P. (2010): Historical Climate in Central Europe During the Last 500 Years. In: Przybylak, R., Majorowicz, J., Brázdil, R., Kejna, M. (eds.): The Polish Climate in the European Context: An Historical Overview. Springer, Dordrecht, Heidelberg, London, New York, pp. 41-70.

BRÁZDIL, R., DOBROVOLNÝ, P., LUTERBACHER, J., MOBERG, A., PFISTER, C., WHEELER, D., ZORITA, E. (2010): European climate of the past 500 years: new challenges for historical climatology. Climatic Change, 101, No. 1-2, pp. 7-40.

BRÁZDIL, R., KOTYZA, O. (1995): History of Weather and Climate in the Czech Lands I. Period 1000-1500. Zürcher Geographische Schriften 62, Zürich, 260 pp.

BRÁZDIL, R., KOTYZA, O. (2000): History of Weather and Climate in the Czech Lands IV. Utilisation of Economic Sources for the Study of Climate Fluctuation in the Louny Region in the Fifteenth - Seventeenth Centuries. Masaryk University, Brno, $350 \mathrm{pp}$.

BRÁZDIL, R., PFISTER, C., WANNER, H., VON STORCH, H., LUTERBACHER, J. (2005): Historical climatology in Europe - the state of the art. Climatic Change, 70, No. 3, pp. 363-430.

BRAZDIL, R., ZAHRADNÍČEK, P., DOBROVOLNÝ, P., KOTYZA, O., VALÁŠEK, H. (2008): Historical and recent viticulture as a source of climatological knowledge in the Czech Republic. Geografie, 113, No. 4, pp. 351-371.

BÜRGER, G. (2007): On the verification of climate reconstructions. Climate of the Past, 3, No. 3, pp. 397-409.

CAMUFFO, D., JONES, P., eds. (2002): Improved understanding of past climatic variability from early daily European instrumental sources. Kluwer Academic Publishers, Dordrecht, Boston, London, $392 \mathrm{pp}$.

CHUINE, I., YIOU, P., VIOVY, N., SEGUIN, B., DAUX, V., LE ROY LADURIE, E. (2004): Historical phenology: Grape ripening as a past climate indicator. Nature, 432, No. 7015, pp. 289-290.

DOBROVOLNÝ, P., BRÁZDIL, R., VALÁŠEK, H., KOTYZA, O., MACKOVÁ, J., HALÍČKOVÁ, M. (2009): A standard paleoclimatological approach to temperature reconstruction in 
historical climatology: an example from the Czech Republic, AD 1718-2007. International Journal of Climatology, 29, No. 10, pp. 1478-1492.

DOBROVOLNÝ, P., MOBERG, A., BRÁZDIL, R., PFISTER, C., GLASER, R., WILSON, R., VAN ENGELEN, A., LIMANÓWKA, D., KISS, A., HALÍČKOVÁ, M., MACKOVÁ, J., RIEMANN, D., LUTERBACHER, J., BÖHM, R. (2010): Monthly and seasonal temperature reconstructions for Central Europe derived from documentary evidence and instrumental records since AD 1500. Climatic Change, 101, No. 1-2, pp. 69-107.

EDDY, J. A. (1976): The Maunder minimum. Science, 192, No. 4245, pp. 1189-1202.

ESPER, J., FRANK, D. C., WILSON, R. J. S., BRIFFA, K. R. (2005): Effect of scaling and regression on reconstructed amplitude for the past millennium. Geophysical Research Letters, 32, L07711.

FISCHER, E. M., LUTERBACHER, J., ZORITA, E., TETT, S. F. B., CASTY, C., WANNER, H. (2007): European climate response to tropical volcanic eruptions over the last half millennium. Geophysical Research Letters, 34, L05707.

GLASER, R. (2008): Klimageschichte Mitteleuropas. 1200 Jahre Wetter, Klima, Katastrophen. Primus Verlag, Darmstadt, 264 pp.

GLASER, R., RIEMANN, D. (2009): A thousand year record of climate variation for Central Europe at a monthly resolution. Journal of Quaternary Science, 24, No. 5, pp. 437-449.

HEGERL, G. C., KARL, T. R., ALLEN, M., BINDOFF, N. L., GILLETT, N., KAROLY, D., ZHANG, X., ZWIERS, F. (2006): Climate change detection and attribution: Beyond mean temperature signals. Journal of Climate, 19, No. 20, pp. 5058-5077.

HLAVÁČ, V. (1966): Jak se jeví kolísání klimatu za posledníich dvě stě roků v pražské teplotní řadě. Meteorologické zprávy, 19, No. 2, pp. 33-42.

JONES, P. D., BRIFFA, K. R. (2006): Unusual climate in northwest Europe during the period 1730 to 1745 based on instrumental and documentary data. Climatic Change, 79, No. 3-4, pp. 361-379.

JONES, P. D., BRIFFA, K. R., OSBORN, T. J., LOUGH, J. M., VAN OMMEN, T. D., VINTHER, B. M., LUTERBACHER, J., WAHL, E. R., ZWIERS, F. W., MANN, M. E., SCHMIDT, G. A., AMMANN, C. M., BUCKLEY, B. M., COBB, K. M., ESPER, J., GOOSSE, H., GRAHAM, N., JANSEN, E., KIEFER, T., KULL, C., KUTTEL, M., MOSLEY-THOMPSON, E., OVERPECK, J. T., RIEDWYL, N., SCHULZ, M., TUDHOPE, A. W., VILLALBA, R., WANNER, H., WOLFF, E., XOPLAKI, E. (2009): High-resolution palaeoclimatology of the last millennium: a review of current status and future prospects. The Holocene, 19, No. 1, pp. 3-49.

KARL, T. R., EASTERLING, D. R. (1999): Climate extremes: selected review and future research directions. Climatic Change, 42, No. 1, pp. 309-325.

KATZ, R. W., BRUSH, G. S., PARLANGE, M. B. (2004): Statistics of extremes: Modeling ecological disturbances. Ecology, 86, No. 5, pp. 1124-1134.

KÜTTEL, M., XOPLAKI, E., GALLEGO, D., LUTERBACHER, J., GARCÍA-HERRERA, R., ALLAN, R., BARRIENDOS, M., JONES, P. D., WHEELER, D., WANNER, H. (2009): The importance of ship log data: reconstructing North Atlantic, European and Mediterranean sea level pressure fields back to 1750. Climate Dynamics, 34, No. 7-8, pp. 1115-1128.

LEIJONHUFVUD, L., WILSON, R., MOBERG, A. (2008): Documentary data as proxy variables for Stockholm late winter to early spring temperatures in the 18th and 19th centuries. The Holocene, 18, No. 2, pp. 333-343.

LEIJONHUFVUD, L., WILSON, R., MOBERG, A., SÖDERBERG, J., RETSÖ, D., SÖDERLIND, U. (2010): Five centuries of winter/spring temperatures in Stockholm reconstructed from documentary evidence and instrumental observations. Climatic Change, 101, No. 1-2, pp. 109-141.

LUTERBACHER, J., DIETRICH, D., XOPLAKI, E., GROSJEAN, M., WANNER, H. (2004): European seasonal and annual temperature variability, trends and extremes since 1500 . Science, 303, No. 5663, pp. 1499-1503.

LUTERBACHER, J., KOENIG, S. J., FRANKE, J., VAN DER SCHRIER, G., ZORITA, E., MOBERG, A., JACOBEIT, J., DELLA-MARTA, P. M., KÜTTEL, M., XOPLAKI, E., WHEELER, D., RUTISHAUER, T., STÖSSEL, M., WANNER, H., BRÁZDIL, R., DOBROVOLNÝ, P., CAMUFFO, D., BERTOLIN, C., VAN ENGELEN, A., GONZALEZ-ROUCO, F. J., WILSON, R., PFISTER, C., LIMANÓWKA, D., NORDLI, Ø., LEIJONHUFVUD, L., SÖDERBERG, J., ALLAN, R., BARRIENDOS, M., GLASER, R., RIEMANN, D., HAO, Z., 
ZEREFOS, C. S. (2010): Circulation dynamics and its influence on European and Mediterranean January-April climate over the past half millennium: results and insights from instrumental data, documentary evidence and coupled climate models. Climatic Change, 101, No. 1-2, pp. 201-234.

LUTERBACHER, J., LINIGER, M. A., MENZEL, A., ESTRELLA, N., DELLA-MARTA, P. M., PFISTER, C., RUTISHAUSER, T., XOPLAKI, E. (2007): The exceptional European warmth of Autumn 2006 and Winter 2007: historical context, the underlying dynamics and its phenological impacts. Geophysical Research Letters, 34, L12704.

MEIER, N., RUTISHAUSER, T., PFISTER, C., WANNER, H., LUTERBACHER, J. (2007): Grape harvest dates as a proxy for Swiss April to August temperature reconstructions back to AD 1480. Geophysical Research Letters, 34, L20705.

PFISTER, C. (1992): Monthly temperature and precipitation in central Europe 1525-1979: quantifying documentary evidence on weather and its effects. In: Bradley, R. S., Jones, P. D. (eds.): Climate since AD 1500. Routledge, London, pp. 118-143.

PFISTER, C. (1999): Wetternachhersage. 500 Jahre Klimavariationen und Naturkatastrophen (1496-1995). Verlag Paul Haupt, Bern, Stuttgart, Wien, 304 pp.

PFISTER, C., BRÁZDIL, R., GLASER, R., BARRIENDOS, M., CAMUFFO, D., DEUTSCH, M., DOBROVOLNÝ, P., ENZI, S., GUIDOBONI, E., KOTYZA, O., MILITZER, S., RÁCZ, L., RODRIGO, F. S. (1999): Documentary evidence on climate in sixteenth-century Europe. Climatic Change, 43, No. 1, pp. 55-110.

PFISTER, C., LUTERBACHER, J., WANNER, H., WHEELER, D., BRÁZDIL, R., GE, Q., HAO, Z., MOBERG, A., GRAB, S., PRIETO, M. R. (2008): Documentary evidence as climate proxies. Proxyspecific White Paper produced from the PAGES/CLIVAR workshop, Trieste, 2008, in: PAGES (Past Global Changes), Bern.

PÍSEK, J., BRÁZDIL, R. (2006): Responses of large volcanic eruptions in the instrumental and documentary climatic data over Central Europe. International Journal of Climatology, 26, No. 4, pp. 439-459.

RODRIGO, F. S. (2008): A new method to reconstruct low-frequency climatic variability from documentary sources: Application to winter rainfall series in Andalusia (Southern Spain) from 1501 to 2000. Climatic Change, 87, No. 3-4, pp. 471-487.

SHABALOVA, M. V., VAN ENGELEN, A. F. V. (2003): Evaluation of a reconstruction of winter and summer temperatures in the Low Countries, AD 764-1998. Climatic Change, 58 , No. 1-2, pp. 219-242.

SOLOMON, S., QIN, D., MANNING, M., MARQUIS, M., AVERYT, K., TIGNOR, M. M. B., LEROY MILLER, H., CHEN, Z., eds. (2007): Climate Change 2007: The Physical Science Basis. Cambridge University Press, Cambridge, New York, Melbourne, Madrid, Cape Town, Singapore, São Paulo, Delhi, 996 pp.

TRIGO, R. M., VAQUERO, J. M., ALCOFORADO, M. J., BARRIENDOS, M., TABORDA, J., GARCIA-HERRERA, R., LUTERBACHER, J. (2009). Iberia in 1816, the year without summer. International Journal of Climatology, 29, No. 1, pp. 99-115.

VON STORCH, H., ZWIERS, F. W. (1999): Statistical Analysis in Climate Research. Cambridge University Press, Cambridge, $484 \mathrm{pp}$.

XOPLAKI, E., LUTERBACHER, J., PAETH, H., DIETRICH, D., STEINER, N., GROSJEAN, M., WANNER, H. (2005): European spring and autumn temperature variability and change of extremes over the last half millennium. Geophysical Research Letters, 32, L15713.

ZORITA, E., MOBERG, A., LEIJONHUFVUD, L., WILSON, R., BRÁZDIL, R., DOBROVOLNÝ, P., LUTERBACHER, J., BÖHM, R., PFISTER, C., GLASER, R., SÖDERBERG, J., GONZÁLEZ-ROUCO, F. (2010) European temperature records of the past five centuries based on documentary information compared to climate simulations. Climatic Change, 101, No. 1-2, pp. 143-168. 


\section{TEPLOTNĚ EXTRÉMNÍ ZIMY A LÉTA V ČESKÝCH ZEMÍCH OD ROKU 1500 A JEJICH STŘEDOEVROPSKÝ KONTEXT}

Současné globální oteplování je často spojováno se zvýšenou pravděpodobností výskytu meteorologických extrémů a klimatických anomálií. K jejich studiu je zapotřebí dlouhých meteorologických řad, které v případě teploty vzduchu začínají ve střední Evropě ve druhé polovině 18. století a pokrývají tak období zesilujícího antropogenního vlivu na klima. Přímá měření však chybějí z předchozího období, ve kterém byla variabilita klimatu podmíněna přírodními faktory. Pro toto období je ale možné využít řady nepřímých (tzv. proxy) údajů, které obsahují zpravidla zprostředkovanou informaci o počasí nebo podnebí. K nim náleží rovněž dokumentární prameny, s nimiž pracuje historická klimatologie a které ve zvýšené míre vyjadřují projevy meteorologických extrémů a klimatických anomálií.

V českých zemích se dokumentární prameny objevují ve větší míře od 16. století. Zpravidla kvalitativní písemné prameny jsou interpretovány a transformovány do podoby indexů charakterizujících např. teplotní poměry každého měsíce $\mathrm{v}$ sedmistupňové škále od -3 (extrémně chladný) do +3 (extrémně teplý). Sezónní teplotní indexy jsou poté součtem odpovídajících měsíčních hodnot (tedy mohou nabývat hodnot od -9 do +9 ). Indexy zimních (prosinec-leden) a letních (červen-srpen) období byly využity $\mathrm{k}$ definování teplotně extrémních sezón v období 1500-1854. Pro instrumentální období byly využity teplotní řady stanice Praha-Klementinum v období 1771-2007. Z obou datových souborů byly jako extrémní definovány případy přesahující hodnoty 5 . a 95 . percentilu normálního rozdělení průměrných zimních a letních teplot vzduchu (obr. 1). Celkem bylo vymezeno 24 extrémně tuhých a 23 extrémně mírných zim, 18 extrémně chladných a 21 extrémně teplých lét (obr. 2). Jejich časový výskyt byl porovnán s rekonstruovanou řadou teploty vzduchu střední Evropy pro období 1500-2007 (obr. 3). Lepší shodu vykazují extrémní zimy v porovnání s extrémními léty. Pro obě studované sezóny se jako nejzřetelnější shluk kladných anomálií jeví období současného globálního oteplování. V období před začátkem prrístrojových měření se výskyt jednotlivých extrémů váže na střednědobý trend. V případě poklesu teplot vzduchu ve střední Evropě se jedná o druhou polovinu 16. století pro zimu i léto a konec 17. století pro zimu. Teplotně extrémní sezóny však souvisejí také s obdobími zvýšené variability klimatu. Takto se jeví především konec 18. a počátek 19. století. V některých př́ípadech lze výskyt extrémních sezón spojovat $\mathrm{s}$ působením přírodních klimatotvorných faktorů jako je vulkanická činnost (viz zima 1783/84 nebo léto 1816). Výskyt teplotně extrémních zim a lét v českých zemích v období před začátkem systematických přístrojových měření se významně shoduje $\mathrm{s}$ výskytem obdobných teplotních anomálií interpretovaných z dokumentárních pramenů z Německa, Švýcarska a Nizozemska (obr. 4).

Vazbu studovaných teplotních extrémů na charakter cirkulace lze vyjádřit průměrným polem přízemního tlaku vzduchu v evropsko-atlantské oblasti (obr. 5a, d). Oproti normálu (1961-1990) jsou extrémně chladné zimy v českých zemích charakterizovány zvýšeným vlivem Asijské anticyklony s přívodem chladného kontinentálního vzduchu (obr. 5b), zatímco pro extrémně mírné zimy je typický pokles tlaku vzduchu západně od Britských ostrovů $\mathrm{s}$ teplou advekcí (obr. 5c). Během extrémně chladných letních sezón zesiluje rozdíl mezi Azorskou tlakovou výší a tlakovou níží nad Islandem (obr. 5e), což vede k chladnému severozápadnímu proudění do střední Evropy. Naproti tomu extrémně teplá léta se vyznačují vzestupem tlaku vzduchu nad střední Evropou (obr. 5f).

Analýza výskytu zimních a letních teplotních extrémů založená na zpracování dokumentárních pramenů a přístrojových měření z českých zemí přispívá k poznání jejich časové a prostorové variability ve střední Evropě za posledních 500 roků a nabízí možnosti jejich porovnání s dalšími proxy údaji. 
Obr. 1 - Histogramy průměrných (a) zimních (prosinec-únor) a (b) letních (červen-srpen) anomálií teploty vzduchu stanice Praha-Klementinum v období 1771-2007 proložené frekvenční funkcí normálního rozdělení. Referenční období 1961-1990.

Obr. 2 - Rozdělení zimních (a) a letních (b) teplotních indexů českých zemí (1500-1854) a průměrných zimních (c) a letních (d) teplot vzduchu Prahy-Klementina (1771-2007) vyjádřených v odchylkách od období 1961-1990. Černé kroužky značí teplotně extrémní sezóny vymezené podle 5 . a 95 . percentilu.

Obr. 3 - Zimní (a) a letní (b) teplotní anomálie střední Evropy (referenční období 1961-1990) shlazené 30letým Gaussovým nízkofrekvenčním filtrem v období 1500-2007. Horizontální čáry indikují nejstudenější a nejteplejší 30leté nepřekrývající se období. Vertikální čáry značí kontinuální klouzavé 30leté sestupné a vzestupné lineární trendy. Trojúhelníky ukazují extrémně studené a teplé sezóny v řadách indexů odvozených z českých dokumentárních údajů (1500-1854) a kroužky totéž v teplotních řadách Prahy-Klementina (1771-2007).

Obr. 4 - Teplotní indexy sestavené podle dokumentárních údajů pro extrémně mírné (a) a extrémně studené (b) zimy a extrémně teplá (c) a extrémně studená (d) léta pro české země (CL), Německo (DE), Švýcarsko (CH) a Nizozemsko (LC) v období 1500-1854. Symbol x značí chybějící indexy.

Obr. 5 - Přízemní tlakové pole odvozené podle Küttela et al. (2009) pro období 1750-1849 a z databáze HadSLP2r (Allen, Ansell 2006) pro období 1850-2007: (a) průměr zimy 1961-1990, (b) průměrné anomálie pro extrémně studené zimy v Praze, (c) průměrné anomálie pro extrémně mírné zimy v Praze, (d) průměr léta 1961-1990, (e) průměrné anomálie pro extrémně studená léta v Praze, (f) průměrné anomálie pro extrémně teplá léta v Praze. Referenční období 1961-1990, jednotky hPa. Černé body značí gridové body, ve kterých jsou zjištěné anomálie statisticky významné na hladině významnosti $95 \%$ podle t-testu.

P. Dobrovolný and R. Brázdil are affiliated with Masaryk University, Faculty of Science, Institute of Geography, Kotlářská 2, 61137 Brno; e-mail: dobro@sci.muni.cz, brazdil@sci. muni.cz. O. Kotyza is affiliated with Regional Museum, Dlouhá 179, 41201 Litoměrice, e-mail: muzeum.ltm@telecom.cz. H. Valášek is affiliated with Moravian Land Archives, Palachovo nám. 1, 62500 Brno; e-mail:valasek@mza.cz.

Initial submission 19 November 2009; final acceptance 13 May 2010.

\section{Citační vzor:}

DOBROVOLNÝ, P., BRÁZDIL, R., KOTYZA, O., VALÁŠEK, H. (2010): Extreme summer and winter temperatures in the Czech Lands after A.D. 1500 and their Central European context. Geografie, 115, č. 3, s. 266-283. 